\title{
Synergids and filiform apparatus in the sexual and apomictic dandelions from section Palustria (Taraxacum, Asteraceae)
}

\author{
Bartosz J. Plachno • Krystyna Musial • Piotr Świątek • \\ Monika Tuleja $\cdot$ Jolanta Marciniuk • \\ Aleksandra Grabowska-Joachimiak
}

Received: 9 April 2013 / Accepted: 8 August 2013 / Published online: 24 August 2013

(C) The Author(s) 2013. This article is published with open access at Springerlink.com

\begin{abstract}
An evolutionary trend to reduce "unnecessary costs" associated with the sexual reproduction of their amphimictic ancestors, which may result in greater reproductive success, has been observed among the obligatory apomicts. However, in the case of the female gametophyte, knowledge about this trend in apomicts is not sufficient because most of the ultrastructural studies of the female gametophyte have dealt with amphimictic angiosperms. In this paper, we tested the hypothesis that, in contrast to amphimictic plants, synergids in apomictic embryo sacs do not form a filiform apparatus. We compared the synergid structure in two dandelions from sect. Palustria: the amphimictic diploid Taraxacum tenuifolium and the apomictic tetraploid, male-sterile Taraxacum brandenburgicum . Synergids in both species possessed a filiform apparatus. In $T$. brandenburgicum, both synergids persisted for a long time without any degeneration, in spite of the presence of an embryo and endosperm. We propose that the persistent synergids in apomicts may play a role in the transport of nutrients to the embryo.
\end{abstract}

Handling Editor: Heiti Paves

B. J. Płachno $(\bowtie) \cdot$ K. Musiał $\cdot$ M. Tuleja

Department of Plant Cytology and Embryology, Jagiellonian

University, 9 Gronostajowa St., 30-387 Cracow, Poland

e-mail: bartosz.plachno@uj.edu.pl

P. Świątek

Department of Animal Histology and Embryology,

University of Silesia, 9 Bankowa St., 40-007 Katowice, Poland

J. Marciniuk

Department of Botany, Siedlce University of Natural Sciences and Humanities, 12 Prusa St., 08-110 Siedlce, Poland

A. Grabowska-Joachimiak

Cytogenetics Group in the Department of Plant Breeding and Seed

Science, University of Agriculture in Cracow, 24 Łobzowska St.,

31-140 Cracow, Poland
Keywords Apomixis · Egg apparatus · Female gametophyte · Filiform apparatus $\cdot$ Synergid $\cdot$ Taraxacum

\section{Introduction}

Apomixis has been documented in about 44 families of flowering plants; however, the best knowledge about this mode of reproduction is based on studies of three families: Asteraceae, Poaceae, and Rosaceae. Approximately $75 \%$ of apomicts belong to these families (Czapik 1996; Noyes 2007). Although studies about apomixis in Asteraceae began at the turn of the nineteenth and twentieth centuries (Noyes 2007), after 100 years, they are still making healthy progress. Most of the embryological investigations in the past were focused on the analysis of female and male meiosis, embryo development, and endosperm formation, while the ultrastructure of the embryo sac has not received sufficient attention.

An evolutionary trend to reduce "unnecessary costs" associated with the sexual reproduction of their ancestors, which may result in greater reproductive success, has been observed among the obligatory apomicts. For example, apomictic malesterile dandelions produce more inflorescences than apomictic dandelions that produce pollen grains (Meirmans et al. 2006). A similar reduction in unnecessary costs (lack of pollen grains produced) was observed in other apomicts such as Alchemilla (Izmaiłow 1986) and Hieracium (Slade and Rich 2007). A specific example is Antennaria alpina s.l., within which hundreds of taxons have been distinguished that are known only from female specimens (Nogler 1984). So, it can be assumed that a cost reduction may also take place in the development of an unreduced female gametophyte. After studying three diplosporous species from Asteraceae, Chondrilla juncea L., Chondrilla brevirostris Fisch. et Mey., and Taraxacum alatum Lindb., Kościńska-Pajak and Bednara (2006) and KościńskaPajak (2006) proposed the hypothesis that, in contrast to 
amphimictic plants, synergids in apomictic embryo sacs have a basic cytoplasmic skeleton and do not form a filiform apparatus (FA) or differentiate cytoplasm. It should be emphasized that the authors published electronograms only for C. juncea; therefore, the hypothesis about the simplified ultrastructure of the synergid in apomicts is based on a single species. Moreover, to date, there has been no detailed data published about the ultrastructure of the egg apparatus in amphimictic species from the mentioned genera, Chondrilla and Taraxacum, which would be very helpful in verifying this hypothesis.

It should also be noted that studies on the ultrastructure of the female gametophyte in apomicts are very rare, e.g., in the case of facultative apomicts, they are limited to the aposporous embryo sacs of Panicum maximum Jacq. (Chen and Guan 2012 and citations therein). The ploidy level in Taraxacum is a good indicator of the mode of reproduction because diploids are obligate sexual, whereas most polyploids are apomicts (Richards 1973; Hörandl 2010). Thus, we chose the diploid Taraxacum tenuifolium (Hoppe \& Hornsch.) Koch and the tetraploid male-sterile Taraxacum brandenburgicum Hudziok, species from the same section, Palustria, to verify the hypothesis that, in contrast to amphimictic plants, synergids in apomictic embryo sacs do not form a filiform apparatus.

\section{Materials and methods}

\section{Plant material}

T. tenuifolium (Hoppe \& Hornsch.) Koch ( $2 n=2 x=16$, Záveský et al. 2005) was collected by Ingo Uhlemann in Croatia and later cultivated in the private collection of J. Marciniuk in Siedlce $\left(52^{\circ} 10^{\prime} 49^{\prime \prime} \mathrm{N}, 22^{\circ} 18^{\prime} 26^{\prime \prime} \mathrm{E}\right)$. Plants of T. brandenburgicum Hudziok $(2 n=4 x=32$; Marciniuk et al. 2010) were collected from a natural population in Pyzdry near Poznań in Poland. Studies were carried out with flowers before anthesis and during anthesis.

\section{Methods}

Light and electron microscopy studies

For the clearing technique, inflorescences were fixed in FAA (40\% formalin/glacial acetic acid $/ 70 \%$ ethanol, 5:5:90, v/v) for $24 \mathrm{~h}$ and stored in $70 \%$ ethanol. Then, isolated ovaries were dehydrated for $1 \mathrm{~h}$ in $70 \%, 80 \%, 90 \%$ (one change), and $100 \%$ ethanol (three changes) and incubated (for $1.5 \mathrm{~h}$ ) in one change of ethanol/methyl salicylate (1:1), one change of ethanol/ methyl salicylate (1:3), and two changes of $100 \%$ methyl salicylate (Young et al. 1979; Musiał et al. 2012, 2013). Cleared ovaries were examined using a Nikon Eclipse 80i microscope equipped with Nomarski interference contrast optics.
The procedure for preparing samples for TEM was as described earlier (Płachno and Świątek 2009, 2010). Briefly, ovaries were fixed in $2.5 \%$ formaldehyde and $2.5 \%$ glutaraldehyde in a $0.05 \mathrm{M}$ cacodylate buffer $(\mathrm{pH} 7.0)$ for 2 days. The material was postfixed in $1 \% \mathrm{OsO} 4$ in a cacodylate buffer for $24 \mathrm{~h}$ at $\sim 4{ }^{\circ} \mathrm{C}$, rinsed in the same buffer, treated with $1 \%$ uranyl acetate in distilled water for $1 \mathrm{~h}$, dehydrated with acetone, and embedded in an Epoxy Embedding Medium Kit (Fluka). Semithin sections were stained with methylene blue and examined using an Olympus BX60 microscope. Ultrathin sections were cut on a Leica Ultracut UCT ultramicrotome. After contrasting with uranyl acetate and lead citrate, the sections were examined using a Hitachi H500 electron microscope at $75 \mathrm{kV}$.

The periodic acid-Schiff (PAS) reaction was used for visualization of the total carbohydrates of insoluble polysaccharides (Weedzony 1996). Additionally, material embedded in Technovit 7100 (Kulzer, Germany) was also used for PAS reaction. All results were the same: total carbohydrates of insoluble polysaccharides stained magenta to purplish red.

\section{Results}

\section{T. tenuifolium}

In the ovules from flowers just before anthesis and during anthesis, in this diploid species, there were mature reduced embryo sacs of the Polygonum type. The egg apparatus consisted of three large pear-shaped cells, two synergids and the egg cell, located in the micropylar part of the embryo sac (Fig. 1a, b). Synergids had the typical polarization; most of the synergid cytoplasm was situated at the micropylar pole while the chalazal pole was highly vacuolated (Fig. 1a). The micropylar apex of the synergids extended slightly into the micropylar canal, which was filled by obturator cells and extracellular matrix (Fig. 1c). At the micropylar end, the synergid wall as well as the adjacent walls of both synergids was thickened (Fig. 1c, d). These walls formed the filiform apparatus. These synergid walls had an irregular, undulating surface (Fig. 1d). The cytoplasm was rich in mitochondria and small vesicles near the filiform apparatus (Fig. 1d). The common synergid wall became increasingly thinner towards the chalazal pole until it completely disappeared (Fig. 2a). The synergid cytoplasm was filled with many endoplasmic reticulum (ER) cisternae and dictyosomes (Fig. 2b).

\section{T. brandenburgicum}

The $T$. brandenburgicum ovary had a single ovule, which was anatropous, tenuinucellar, and unitegmic (Fig. 3a). The micropylar canal of the ovule was filled with an extracellular matrix. In this apomictic species, most of the ovules from flowers just 
Fig. 1 T. tenuifolium. a

Micropylar pole of the embryo sac with egg apparatus; $E g$ egg cell, It integumentary tapetum (endothelium), $S$ synergid cell. b Micropylar part of the ovule with a visible micropylar canal and embryo sac surrounded by endothelium; $E g$ egg cell, It integumentary tapetum (endothelium), $S$ synergid, $\mathrm{Fa}$ filiform apparatus. c

Electronogram of the micropylar pole of synergid cells $(S)$ and a fragment of the micropylar canal filled with extracellular matrix $(E C M)$. d Magnification of the synergid cytoplasm and filiform apparatus $(\mathrm{Fa})$; note numerous vesicles $(v)$ and mitochondria $(m)$ in the micropylar part of the cytoplasm; $d$ dictyosome. Bars: a, b $10 \mu \mathrm{m} ; \mathbf{c} 1.7 \mu \mathrm{m} ; \mathbf{d} 0.6 \mu \mathrm{m}$
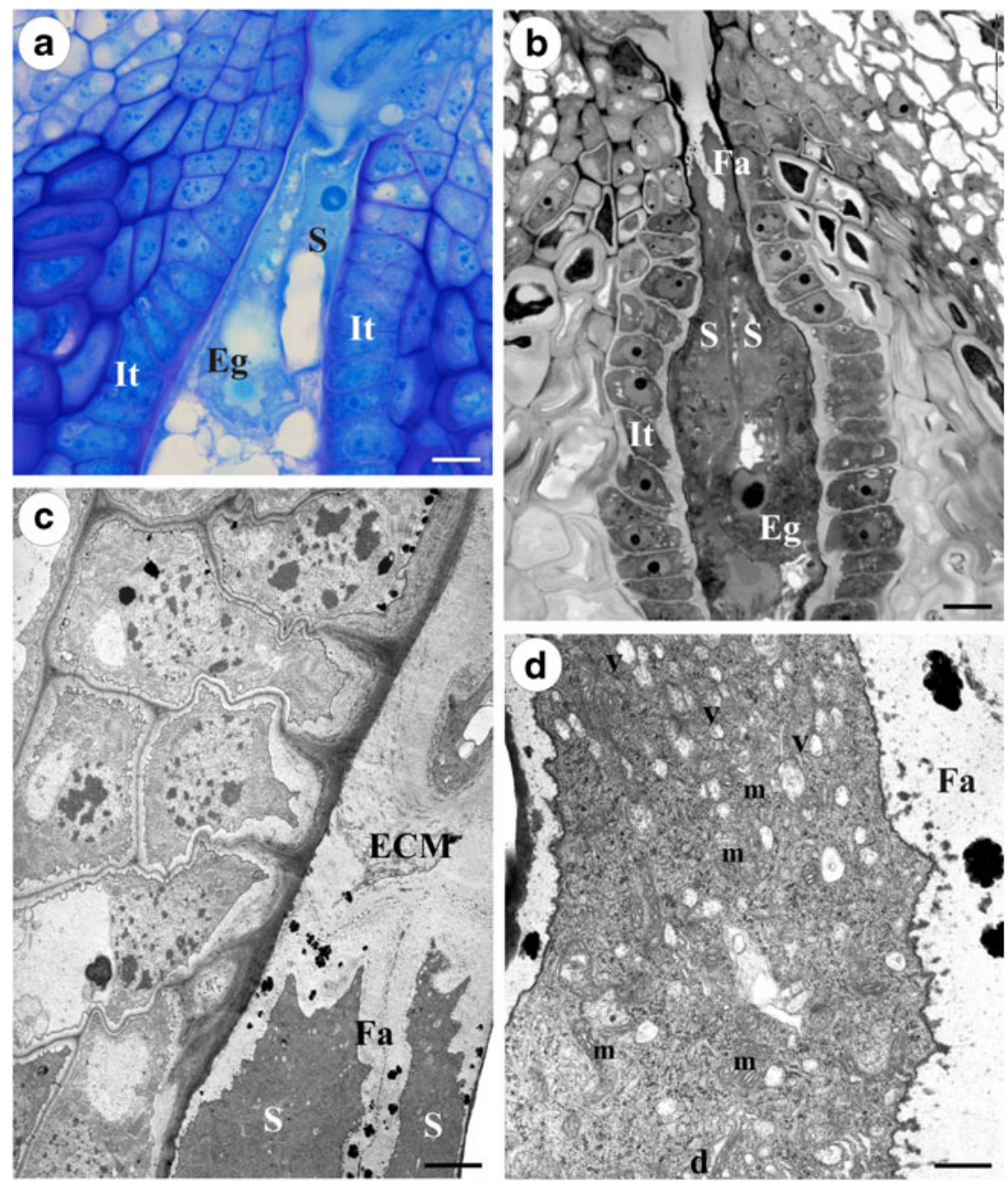

before anthesis contained the mature embryo sacs organized according to the Polygonum type (Fig. 3a, b), but embryo and endosperm formation were also observed in some of the embryo sacs (Fig. 3c). In addition, there were embryos and endosperm in the ovules from flowers during anthesis (Fig. 3d). In the autonomous apomictic dandelion, as in most sexually reproducing plants, the egg apparatus consisted of three large pear-shaped cells: two synergids
Fig. 2 T. tenuifolium.

Ultrastructure of synergid cells. a Filiform apparatus $(\mathrm{Fa})$ and synergid wall increasingly thinner toward the chalazal pole. b Cytoplasm rich in ER cisternae $(E r)$ dictyosomes $(d)$ and vesicles (v); $S$ synergid, black star adjacent walls of both synergids, $m$ mitochondrion. Bars:

a $0.9 \mu \mathrm{m}, \mathbf{b} 0.3 \mu \mathrm{m}$
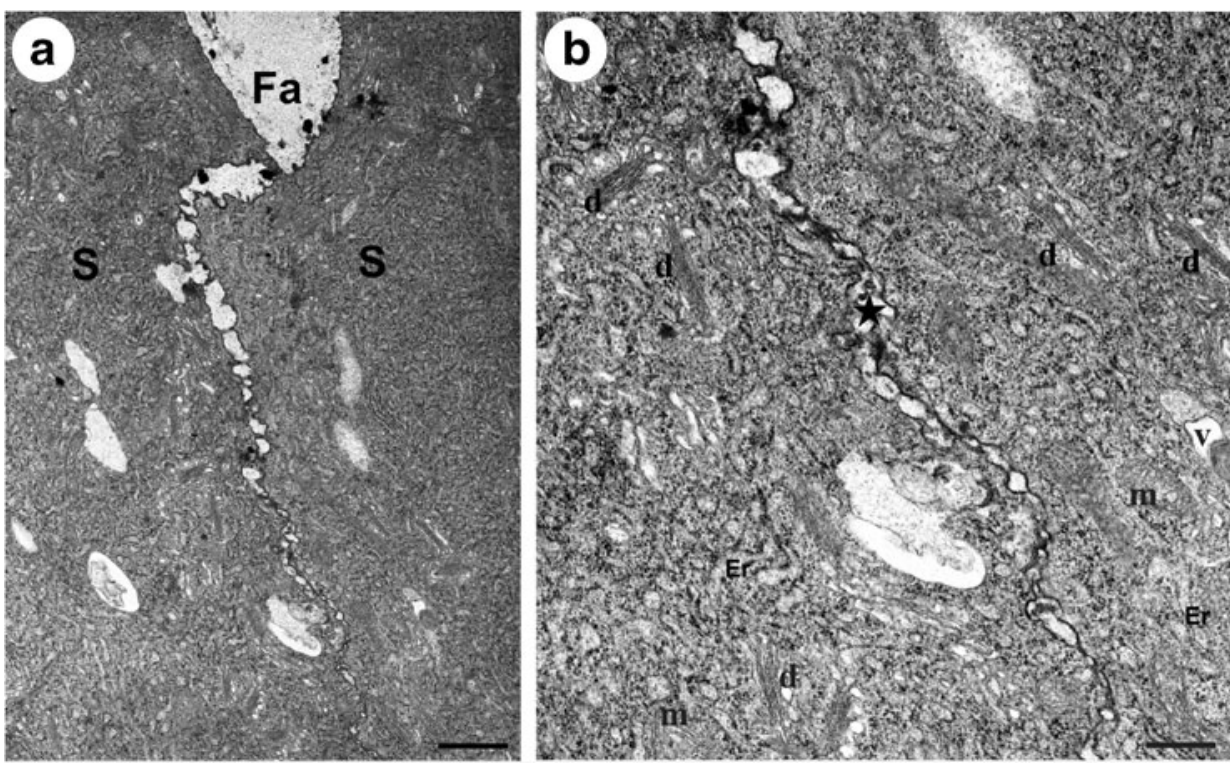


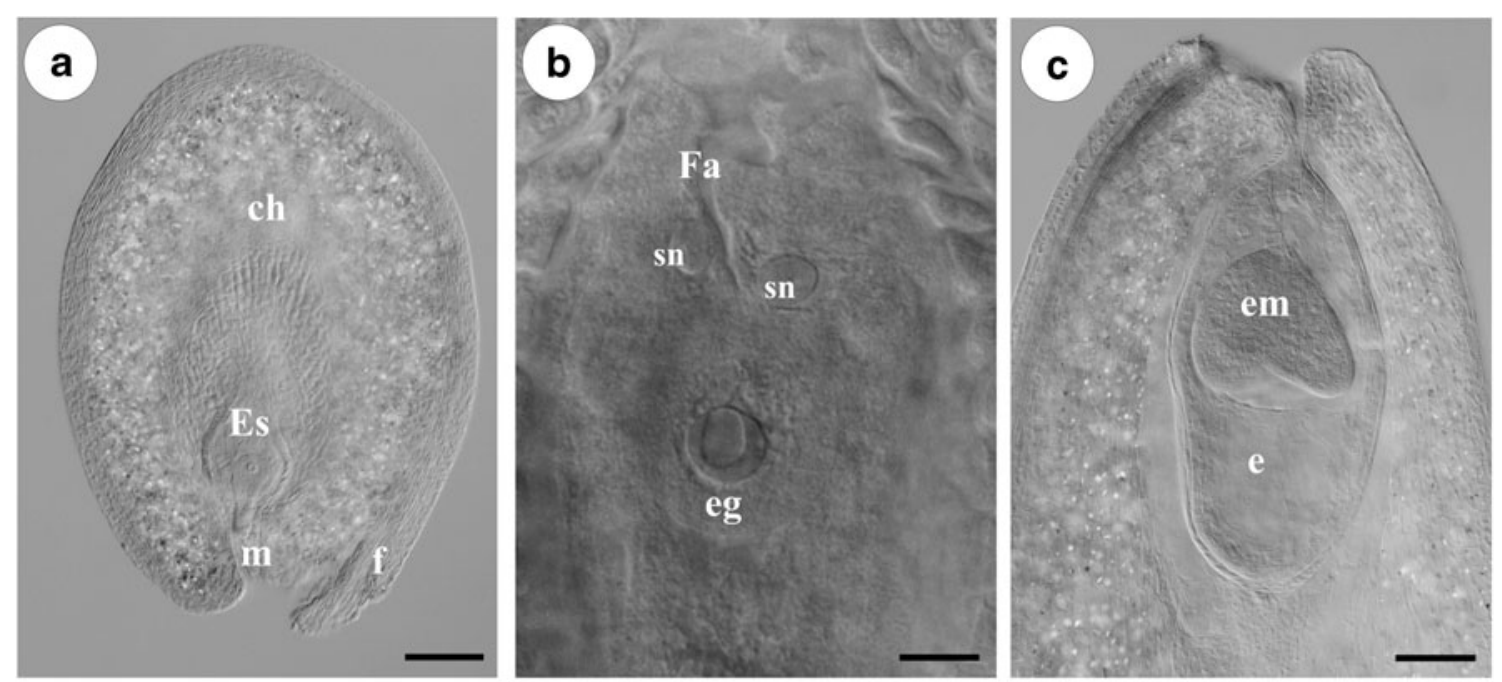

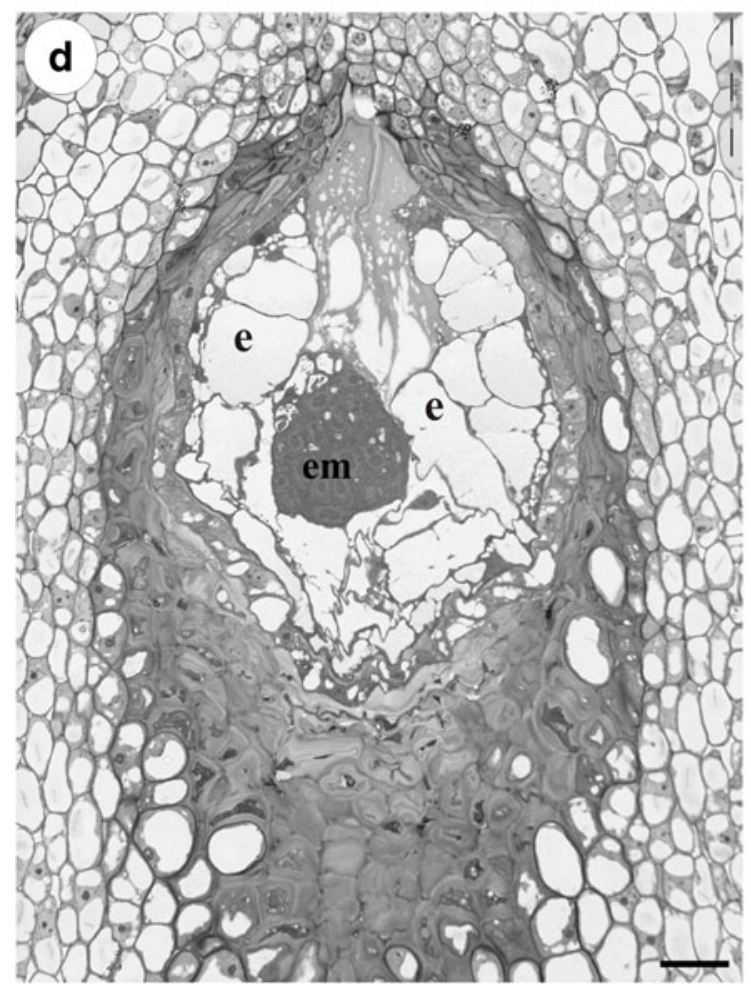

Fig. 3 T. brandenburgicum. Structure of the ovule, embryo sac, embryo, and endosperm. a-c Images from cleared material using Nomarski DIC optics. a Anatropous, unitegmic, tenuinucellate ovule; ch chalaza, Es embryo sac, $f$ funicle, $m$ micropyle. b Egg apparatus; eg egg cell, $s n$ synergid nucleus, $\mathrm{Fa}$ shows the filiform apparatus. c Ovule with an

and the egg cell (Fig. 3b). These cells had the typical polarization. At the micropylar pole of synergid cells, adjacent walls of both synergids were thickened forming the filiform apparatus (Fig. 3b). Both synergids persisted for a long time without any degeneration, in spite of the presence of an embryo and endosperm (Fig. 3d, e). The filiform apparatus gave a positive PAS reaction (Fig. 4a). The cytoplasm of both persistent synergids was rich in ER cisternae, and some vesicles and mitochondria occurred

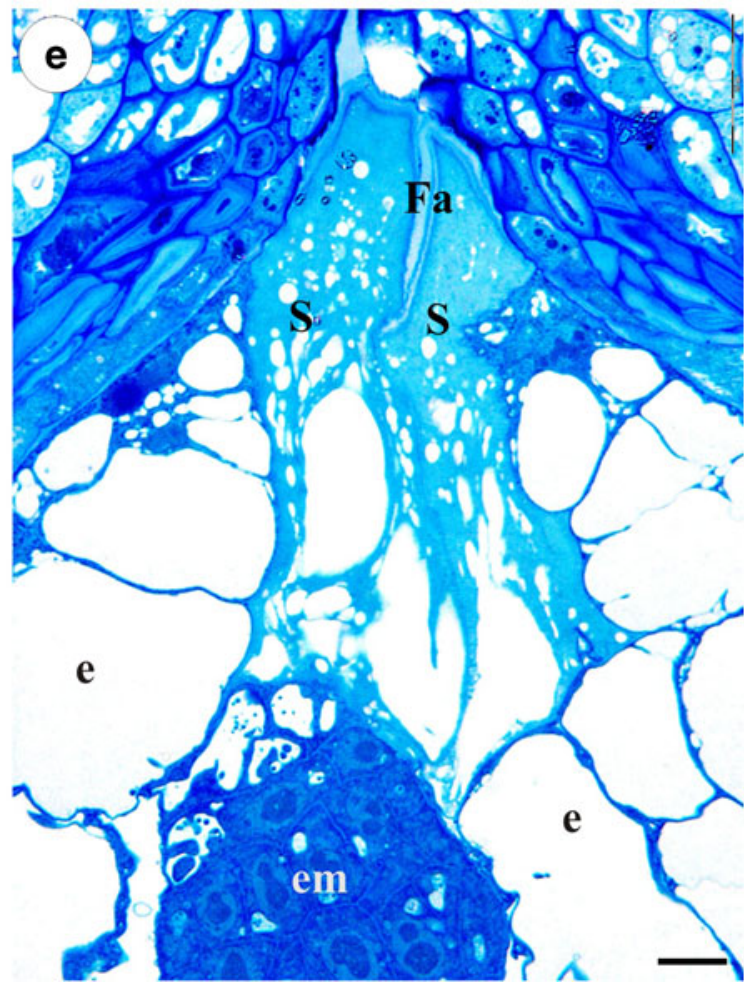

embryo sac containing a cellular endosperm $(e)$ and heart-shaped embryo (em). d, e Semithin section through a young seed showing the cellular endosperm (e), globular embryo ( $\mathrm{em})$, and two synergids $(\mathrm{S}) ; \mathrm{Fa}$ indicates the filiform apparatus. Bars: a, c $100 \mu \mathrm{m} ; \mathbf{b}$, e $10 \mu \mathrm{m} ; \mathbf{d} 25 \mu \mathrm{m}$

(Fig. 4b). Adjacent walls of both synergids became increasingly thinner toward the chalazal pole until it completely disappeared (Fig. 4b).

\section{Discussion}

Synergids are specialized cells that play crucial roles in many stages of the reproductive process of flowering plants. The 
Fig. 4 T. brandenburgicum. a Semithin section showing the micropylar part of the ovule after PAS reaction; $e$ endosperm, $E C M$ extracellular matrix, Em embryo, Int integument, $\mathrm{S}$ synergid, $\mathrm{Fa}$ filiform apparatus. b Electron micrograph showing a fragment of the persistent synergid cytoplasm rich in endoplasmic reticulum $(E r) ; F a$ filiform apparatus, $v$ vesicle, $m$ mitochondria. Bars: a $10 \mu \mathrm{m}$, b $1.2 \mu \mathrm{m}$
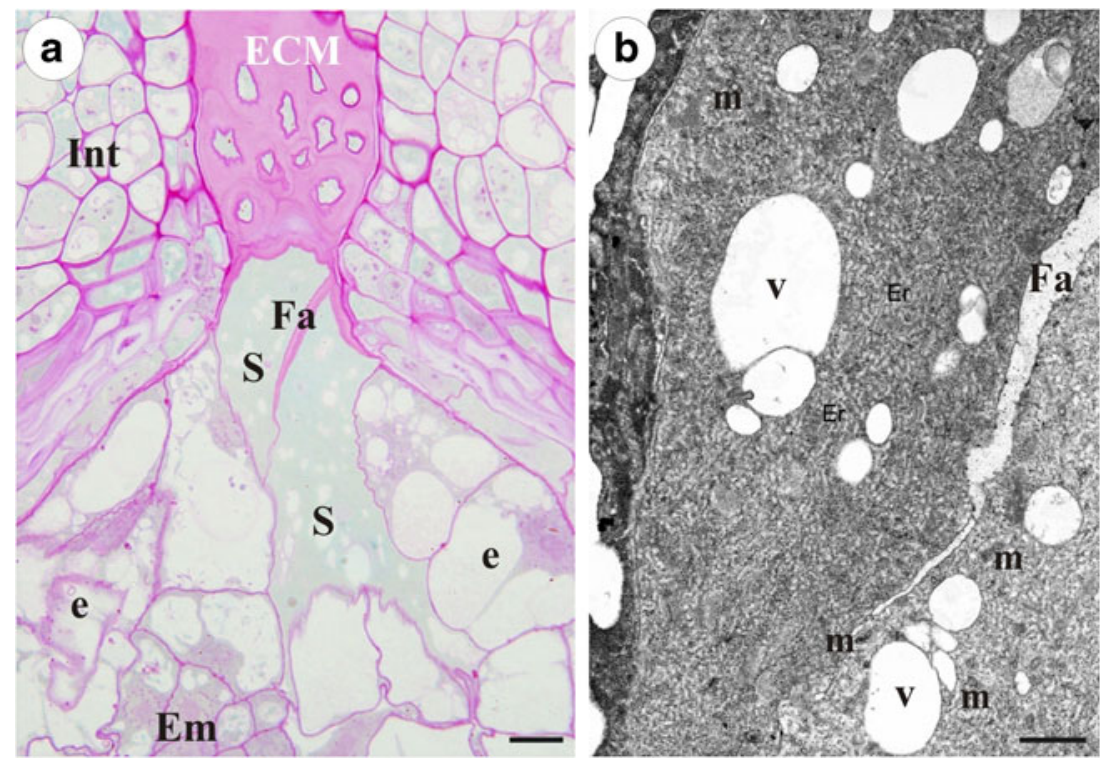

synergid cells are particularly involved in controlling the final stages of pollen tube attraction and reception, its discharge as well as gamete fusion (reviewed in Higashiyama 2002; Punwani and Drews 2008; Higashiyama and Hamamura 2008; Li et al. 2009). To date, there have only been a few studies about the structure of the egg apparatus, synergid activity, and ovule receptivity in autonomous apomicts in which the asexual formation of seeds takes place without the necessity of pollination. However, it was shown experimentally that in apomictic dandelions, in spite of the presence of an embryo and endosperm, pollen tubes penetrate the one of the synergid (van Baarlen et al. 2002). This suggests that, in autonomous apomicts, both the synergid and the micropylar part of the ovule may successfully attract pollen tubes. Our present observations confirmed that, in dandelions, regardless of their reproduction mode, the micropylar canal of the ovule is filled with an extracellular matrix, and that the synergid cells appear to have a high metabolism. The development of the filiform apparatus as well as the presence of endoplasmic reticulum, mitochondria, dictyosomes, and numerous vesicles in the cytoplasm was distinctive for synergids in both the amphimictic T. tenuifolium and the apomictic $T$. brandenburgicum. Thus, these findings do not support the suggestion by Kościńska-Pająk (2006) and KościńskaPająk and Bednara (2006) that, in contrast to amphimictic plants, synergids of autonomous apomicts remain in the juvenile phase and do not form a filiform apparatus or differentiated cytoplasm.

The morphology and structure of the FA in angiosperms vary widely, but its organization seems to be similar within each family (Willemse and van Went 1984; Huang and Russel 1992). In most species, the filiform apparatus has the form of a highly thickened and extensively invaginated cell wall at the micropylar pole of the synergid, and its structure which includes numerous fingerlike projections into the synergid cytoplasm is similar to the transfer cell walls (Huang and Russel 1992; Higashiyama 2002; Punwani and Drews 2008). A classical FA comprises an elaborate system of highly branched projections was identified, for example, in Scilla sibirica, Amaranthus hypochondriacus, and Passiflora caerulea (Bhandari and Sachdeva 1983; Coimbra and Salema 1999; Amela García et al. 2003). In contrast, in the Taraxacum species examined, morphological analysis using light and electron microscopy revealed that the FA is wedge shaped and without a typical labyrinth of ingrowths, and simply appears as a thickening of the common wall separating the two synergids. A similar nature of the FA was found in other members of the Asteraceae, i.e., in Helianthus annuus (Newcomb 1973; Yan et al. 1991) and Cynara cardunculus (Figueiredo et al. 2006). It should be added that Kuroiwa (1989) reported that the synergids of Crepis capillaris (Asteraceae) lack a FA; in spite of this, distinctly thickened walls between the synergids at the micropylar pole can be observed in the figures presented by that author. This suggests that the FA can occur in this species, although not in the classical pattern of organization of other Asteraceae members. The FA most often has a heterogeneous structure that involves fibrillar and amorphous fractions, as was observed in TEM preparations of Petunia hybrida (van Went 1970), Nicotiana tabacum (Mogensen and Suthar 1979), Solanum muricatum (Kopcińska et al. 2002), Genlisea aurea, Utricularia quelchii (Płachno 2011), and numerous other angiosperms. However, the FA in Taraxacum species seems to be homogeneous as it was previously reported in Helianthus (Newcomb 1973).

It is well known that in amphimictic plants, the synergid cell that receives the pollen tube undergoes cell death either before or upon the entry of the pollen tube (Raghavan 1997; 
Sandaklie-Nikolova et al. 2007; Punwani and Drews 2008). Generally, synergid cells have a limited life span and rarely does one of them persist for a time after fertilization. Persistent synergids have been reported, among others, in Allium angulosum, where the polyploid synergid cell retained its physiological activity up to the globular proembryo stage (Euszczek and Bohdanowicz 2010) as well as in Cortaderia species, where the synergids developed into haustoria visible up to the proembryo globular stage (Philipson 1977, 1981). A nutritional role of persistent synergids was suggested in both of these taxa. It is highly likely that in the apomictic $T$. brandenburgicum, the persistent synergids that accompany the embryo and endosperm are also involved in the nutrition of the embryo sac and the developing embryo.

\section{Conclusions}

We found the filiform apparatus in synergids of both amphimictic diploid and apomictic tetraploid dandelions; thus, we do not support the hypothesis that, in contrast to amphimictic plants, synergids do not form a filiform apparatus in apomictic embryo sacs. We suggest that, in apomictic dandelions, the persistent synergids may play a role in the nutrition of the developing embryo.

Acknowledgments This study was funded by grant N N303 807940 from the Polish Ministry of Science and Higher Education/NCN. BJ Płachno gratefully acknowledges the scholarship for Outstanding Young Scientists from the Minister of Science and Higher Education.

Conflict of interest The authors declare that they have no conflict of interest.

Open Access This article is distributed under the terms of the Creative Commons Attribution License which permits any use, distribution, and reproduction in any medium, provided the original author(s) and the source are credited.

\section{References}

Amela García MT, Galati BG, Anton AM (2003) Development and ultrastructure of the megagametophyte in Passiflora caerulea L. (Passifloraceae). Bot J Linn Soc 142:73-81

Bhandari NN, Sachdeva A (1983) Some aspects of organization and histochemistry of the embryo sac of Scilla sibirica Sato. Protoplasma 116:170-178

Chen L, Guan L (2012) Ultrastructural mechanisms of aposporous embryo sac initial cell appearance and its developmental process in gametophytic apomicts of Guinea grass (Panicum maximum). In: Maaz K (ed) The transmission electron microscope. InTech, Rijeka, http://www.intechopen.com/books/thetransmission-electronmicroscope/ultrastructural-mechanism-of-aposporous-intialcellappearance-and-its-developmental-process-in-game. ISBN 978-95351-0450-6
Coimbra S, Salema R (1999) Ultrastructure of the developing and fertilized embryo sac of Amaranthus hypochondriacus L. Ann Bot 84:781-789

Czapik R (1996) Problems of apomictic reproduction in the families Compositae and Rosaceae. Folia Geobot Phytotx 31:381-387

Figueiredo R, Duarte P, Pereira S, Pissarra J (2006) The embryo sac of Cynara cardunculus: ultrastructure of the development and localisation of the aspartic proteinase cardosin B. Sex Plant Reprod 19:93-101

Higashiyama T (2002) The synergid cell: attractor and acceptor of the pollen tube for double fertilization. J Plant Res 115:149-160

Higashiyama T, Hamamura Y (2008) Gametophytic pollen tube guidance. Sex Plant Reprod 21:17-26

Hörandl E (2010) The evolution of self-fertility in apomictic plants. Sex Plant Reprod 23:73-86

Huang B-Q, Russell SD (1992) Female germ unit: organization, isolation, and function. Int Rev Cytol 140:233-292

Izmaiłow R (1986) Cyto-embryological studies on Alchemilla L. (series Calycinae Buser). II. Apomictic processes in ovules. Acta Biol Cracov Ser Bot 28:39-63

Kopcińska J, Łotocka B, Kowalczyk K, Kobryń J (2002) Flower organs of Solanum muricatum Aiton. II. Pistil. Acta Biol Cracov Ser Bot 44:135-143

Kościńska-Pająk M (2006) Biologia rozmnażania apomiktycznych gatunków Chondrilla juncea L., Chondrilla brevirostris L. i Taraxacum alatum Lindb. z uwzględnieniem badań ultrastrukturalnych i immunocytochemicznych. KonTekst, Kraków, pp 1-104

Kościńska-Pająk M, Bednara J (2006) Unusual microtubular cytoskeleton of apomictic embryo sac of Chondrilla juncea L. Protoplasma 227:87-93

Kuroiwa H (1989) Ultrastructural examination of embryogenesis in Crepis capillaris (L.). Wallr.: 1 . The synergid before and after pollination. Bot Mag Tokyo 102:9-24

Li DX, Lin MZ, Wang YY, Tian HQ (2009) Synergid: a key link in fertilization of angiosperms. Biol Plant 53:401-407

Łuszczek D, Bohdanowicz J (2010) Polyploid synergids in Allium angulosum. Abstracts of the XXIX Conference on EmbryologyPlants, Animals, Humans, May 19-21, 2010, Toruń, Ciechocinek. Acta Biol Cracov Ser Bot 52(suppl 1):27

Marciniuk J, Rerak J, Grabowska-Joachimiak A, Jastrząb I, Musiał K, Joachimiak AJ (2010) Chromosome numbers and stomatal cell length in Taraxacum sect. Palustria from Poland. Acta Biol Cracov Ser Bot 52(1):117-121

Meirmans PG, Den Nijs HCM, Van Tienderen PH (2006) Male sterility in triploid dandelions: asexual females vs asexual hermaphrodites. Heredity 96:45-52

Mogensen HL, Suthar HK (1979) Ultrastructure of the egg apparatus of Nicotiana tabacum (Solanaceae) before and after fertilization. Bot Gaz 140:168-179

Musiał K, Kościńska-Pająk M, Sliwinska E, Joachimiak AJ (2012) Developmental events in ovules of the ornamental plant Rudbeckia bicolor. Nutt Flora 207:3-9

Musiał K, Płachno BJ, Świątek P, Marciniuk J (2013) Anatomy of ovary and ovule in dandelions (Taraxacum, Asteraceae). Protoplasma 250:715-722. doi:10.1007/s00709-012-0455-x

Newcomb W (1973) The development of the embryo sac of sunflower Helianthus annuus before fertilization. Can J Bot 51:863-878

Nogler GA (1984) Gametophytic apomixis. In: Johri BM (ed) Embryology of angiosperms. Springer, Berlin, pp 475-518

Noyes RD (2007) Apomixis in the Asteraceae: diamonds in the rough. Funct Plant Sci Biotechnol 1:207-222

Philipson MN (1977) Haustorial synergids in Cortaderia (Gramineae). N Z J Bot 15:777-778

Philipson MN (1981) The haustorial synergids of Cortaderia (Gramineae). Acta Soc Bot Pol 50:151-160 
Płachno BJ (2011) Female germ unit in Genlisea and Utricularia, with remarks about the evolution of the extra-ovular female gametophyte in members of Lentibulariaceae. Protoplasma 248:391-404

Płachno BJ, Światek P (2009) Functional anatomy of the ovule in Genlisea with remarks on ovule evolution in Lentibulariaceae. Protoplasma 236:39-48

Płachno BJ, Świątek P (2010) Unusual embryo structure in viviparous Utricularia nelumbifolia with remarks on embryo evolution in genus Utricularia. Protoplasma 239:69-80

Punwani JA, Drews GN (2008) Development and function of the synergid cell. Sex Plant Reprod 21:7-15

Raghavan V (1997) Molecular embryology of flowering plants. Cambridge University Press, Cambridge, pp 293-317

Richards AJ (1973) The origin of Taraxacum agamospecies. Bot J Linn Soc 66:189-211

Sandaklie-Nikolova L, Palanivelu R, King EJ, Copenhaver GP, Drews GN (2007) Synergid cell death in Arabidopsis is triggered following direct interaction with the pollen tube. Plant Physiol 144:175-1762
Slade K, Rich TCG (2007) Pollen studies in British Hieracium sect. Alpina (Asteraceae). Watsonia 26:443-450

van Baarlen P, Hans de Jong J, van Dijk P (2002) Comparative cytoembryological investigations of sexual and apomictic dandelions (Taraxacum) and their apomictic hybrids. Sex Plant Reprod 15:31-38

van Went JL (1970) The ultrastructure of the synergids of Petunia. Acta Bot Neerl 19:121-132

Wędzony M (1996) Fluorescence microscopy for botanists (in Polish). Dept. Plant Physiology Monographs 5. Kraków, Poland, p 128

Willemse MTM, van Went JL (1984) The female gametophyte. In: Johri BM (ed) Embryology of angiosperms. Springer, Berlin, pp 159-196

Yan H, Yang H, Jensen W (1991) Ultrastructure of the micropyle and its relationship to pollen tube growth and synergid degeneration in sunflower. Sex Plant Reprod 4:166-175

Young BA, Sherwood RT, Bashaw EC (1979) Cleared-pistil and thicksectioning techniques for detecting aposporous apomixis in grasses. Can J Bot 57:1668-1672

Záveský L, Jarolímová V, Štěpánek J (2005) Nuclear DNA content variation within the genus Taraxacum (Asteraceae). Folia Geobot 40:91-104 